\title{
Artisanal Petroleum Refining and Occupational Dynamics in the Niger Delta Region, Nigeria
}

\author{
IGBEN, JL \\ Department of Environmental Management and Toxicology, Western Delta University, Oghara, Nigeria \\ Email: joma_igben@yahoo.com; Tel: 2348034037691
}

\begin{abstract}
This study examines the occupational dynamics of the population as a result of artisanal refining of crude oil in the Niger Delta using structured questionnaire administered to 240 household heads selected from two settlements, one far from area of artisanal refineries (controlled settlement) and the other in area of artisanal refineries (experimental settlement). The questionnaire covered location and demographic characteristics of the respondents, as well as the typology of occupations. The pair-wise Student t-test and simple percentages were used to analyse the data collected. The study revealed that there were significant dynamics $(\mathrm{t}=-0.22, \mathrm{df}=12, \mathrm{p}<0.05)$ in the number of respondents in identified occupational typologies as indirect impact of artisanal refining in the experimental and controlled settlements. The study recommends the intensification of efforts to implement existing laws on environmental protection and provision of employment for teeming population.
\end{abstract}

\section{DOI: https://dx.doi.org/10.4314/jasem.v25i3.6}

Copyright: Copyright $(\odot 2021$ Igben. This is an open access article distributed under the Creative Commons Attribution License (CCL), which permits unrestricted use, distribution, and reproduction in any medium, provided the original work is properly cited.

Dates: Received: 12 December 2020; Revised: 26 January 2021; Accepted: 12 February 2021

Keywords: Artisanal Refineries, Occupational structure, Environmental degradation, Niger Delta.

Refining of petroleum or hydrocarbon involves the transformation of crude oil by way of distillation into various products: thereby adding value to the resource and making it usable by the consumers. The laws empowering such industrial ventures usually stipulate measures of ameliorating or controlling the environmental impact of such operations. Asimiea and Omokhua's (2013) study of the impact of illegal refining of crude oil on the vegetation in the Niger Delta showed that the activities severely impacted on the biodiversity, aesthetic scenery of the forest, regeneration of plant species and destruction of wildlife habitat, disruption of water cycle and loss of medicinal plant species. In the same vein, Nwakwoala et al (2017) study of the impact of artisanal refining of crude on soil and water quality in parts of Okrika and Ogu-Bolo areas of River State in Niger Delta revealed a Water Quality Index rating of 1, which indicated that the water is bad. In addition, the physio-chemical analysis of soil and water revealed poor water and soil. Water analysis showed high concentration of Iron $(\mathrm{Fe})$ and Zinc $(\mathrm{Zn})$ which made the water unsuitable for drinking. Soil samples also recorded high levels of crude content from $1 \mathrm{~m}$ with concentration reducing depth up to 3 metres. In a similar study of the impact of artisanal refining of crude on the vegetation and soil quality in Warri South wetland, Yabrade and Tanee (2010) observed that there is a drastic reduction in the vegetation indices such as frequency of occurrence, abundance, total species content while there was significant increase in Total Hydrocarbon Content (THC), Total Organic Carbon (TOC) in refining sites as against lower THC and TOC in controlled areas. The authors concluded that artisanal refining activity in the study area is disastrous to the wetland ecosystem. Douglas and Cornelius (2019) study of the impact of artisanal refining on soil microorganisms in $\mathrm{Ke}$, Rivers State showed that the continuous contamination of soils by the activity of artisanal refining leads to decrease in microbial population and diversity, which may result in devastating ecological damage that may affect food chain and in turn animals and humans. Commenting on the impact of artisanal refining of crude, Nigerian NRC (2014) stated that the environment is severely damaged at all illegal refining sites. The most obvious signs are dirty water in the rivers with sheen of oil visibly floating on the surface and frequently littering the riverbanks with lumps of oil. As a result, the vegetation along the riverbank are dying, as are the vegetation in the vicinity of the camp. In fact, stakeholders in the oil and gas industry have described illegal artisanal refining in Nigeria as a major source of pollution (DPR, 2018). The degradation of the ecosystem which provides source of livelihood for the population of the rural areas where the illegal refining activities are located impacts on the 
local people in the form of dynamics in occupations. Occupational dynamics refer to changes in the occupational structure or characteristics of the population. According to Igben (2014), it is determined by both internal and external factors. The former comprises an individual's acquired skill, age, sex and marital status while the latter comprise the prevailing economic activity and dynamics in an individual's geographical area. In this study, it is influence by the presence of artisanal refining activities. In spite of the plethora of studies and comments on the impact of artisanal refining on the physical environment of the Niger Delta, there are no known study of the impact of this activity on the social environment particularly on the changes in occupational structure of the people; hence, this study examines the occupational changes of the population in areas where the activity is carried out. Specifically, the study attempts a comparison of the occupational structure of the population in areas of artisanal refining activity and areas where there no such activity.

\section{MATERIALS AND METHOD}

Study Area: The Niger Delta region from the colonial days comprises the administrative divisions of Ahoada, Brass, Degema, Opobo, Ogoni, Western Ijaw and Warri. These administrative divisions are in the present-day Rivers, Bayelsa and Delta States. The definition of the oil-rich region nowadays has been extended to include any geo-political state with an appreciable quantity of petroleum resource. Based on such definition, the region covers nine states, namely, Edo, Delta, Cross River, Akwa Ibom, Bayelsa, Rivers, Imo, Ondo and Abia States (NDDC, 2004; Kiikpoye, 2003), as depicted in Figure 1. The area lies roughly between Latitudes $4^{0} 00^{\prime}$ and $7^{0} 30^{\prime}$ north and Longitudes $4^{0} 00^{\prime}$ and $7^{0} 30^{\prime}$ east, over an area of 112,100 square kilometres, about 12 per cent of the total land area of Nigeria. The region is bordered in the south by the Atlantic Ocean and to the east by the Republic of Cameroun. To the west, the region is bordered by the southwestern states of Lagos, Ogun and Osun. The states of Benue, Kogi, Enugu, Ebonyi and Anambra border the region to the north.

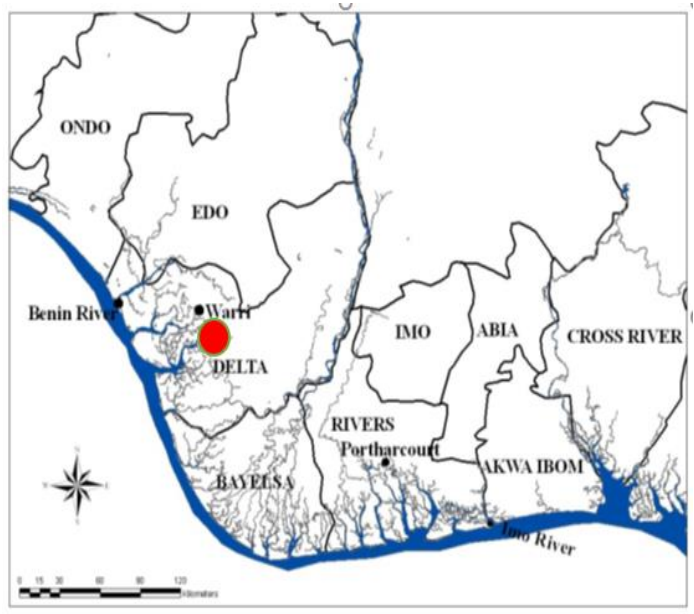

Fig 1: Niger Delta States showing study Area

Furthermore, the area consists of four ecological zones, of coastal barrier island or ridges, mangroves, fresh water swamp forest and lowland rainforest. These zones were classified by Ikporukpo (1996) into two, namely, the outer delta; which comprise muddy sheltered creeks, deltas, brackish and or strong tidal waters characterized by mangrove (Rhizophora race mosa) as the most common plant. Associated with the mangrove forest are Conocarpus erectus and other woody species that grow at the edge of the swamps, mainly near the sea. The south also has fresh water swamps, noted for floating grass, screw pine (Pandanas candelebrum) and raffia palm (Raphia hookeri) as the most common tree types. The inner delta, is made up predominantly of swamp rainforest which is not as wet. The zone comprises wet lowland evergreen rainforest in the north and mangrove forests in the south. The different ecological zones provide habitation for different species of plants, fishes, reptiles, mammals and minerals on which the population depend.

Population and Sample: A total of 240 households were targeted in the two settlements, with 120 households being from each settlement. At the end of the data collection exercise, all the questionnaires were retrieved from the respondents. The questionnaire used for the study was designed to cover all facets of the study. Each question was brief and carefully worded so that it was comprehended by the respondents in a way desired by the researcher. The questions were also presented in a systematic manner so that responses could be related to one or other aspects of the study. It comprises questions on location and demographic characteristics of the respondents, as well as the typology of occupations. Occupations covered in the primary sector are farming (arable and animal husbandry), fishing, hunting, lumbering, fuel wood gathering, raffia and rubber tapping, palm nut 
collection and others such as trading, oil business and civil service.

Data Analysis: Data collected for the study were coded and compacted into manageable size. The frequencies of occurrence of events and percentages were worked out and presented in tables. The process of data analysis was facilitated by the use of the Statistical Package for Social Sciences (SPSS 25.0 version). The pair-wise Student t-test was used to test the significant difference between the occupational structure, on a case-by-case basis, of the Experimental (B) and Controlled (A) settlements. In other words, it was used to test the hypothesis that the dynamics in occupations of the population as a result of artisanal refining of hydrocarbon is not significant.

\section{RESULT AND DISCUSSIONS}

Age and Sex Composition of Sampled Households Heads: Table 1 below shows the age and sex characteristics of the sampled population of the study area.

Table 1 indicates that majority of the total sampled population of 128 household heads representing 53.3 per cent, were above the age of 46 years. Out of this percentage, 38 persons or 15.8 per cent of them were in the age cohort of 51-55 years, closely followed by those between 46-50 years old ( 35 persons or $14.6 \%$ ) and those in the 56-60 years with 29 persons or 12.1 per cent. Those above 60years were 26 persons or 10.8 per cent. Those whose ages were between $41-45$ years were 32 persons or $13.3 \%$, and 10.0 per cent and 10.4 per cent respectively for 35-40 years and 41-45 years old. The percentages became lower with decreasing ages, as those between 31-35 years, 26-30 years, 20-25years and below 20 years formed $10.4 \%$, $5.4 \%, 4.6 \%$ and $3.0 \%$ respectively. In addition, a majority of the household heads were males representing 52.0 per cent in contrast to a lower percentage of 48.0 per cent females.

Table 1: Age and Sex Composition of Sampled Household Heads

\begin{tabular}{llllll}
\hline \multicolumn{2}{l}{ Age Group } & Males & Females & Total & Percentage \\
\hline 1 & Below 20years & 5 & 3 & 8 & 3.0 \\
2 & $21-25$ & 6 & 5 & 11 & 4.6 \\
3 & $26-30$ & 9 & 4 & 13 & 5.4 \\
4 & $31-35$ & 11 & 14 & 25 & 10.4 \\
5 & $36-40$ & 14 & 10 & 24 & 10.0 \\
6 & $41-45$ & 16 & 16 & 32 & 13.3 \\
7 & $46-50$ & 18 & 17 & 35 & 14.6 \\
8 & $51-55$ & 20 & 18 & 38 & 15.8 \\
9 & $56-60$ & 19 & 10 & 29 & 12.1 \\
10 & Above 60 years & 6 & 20 & 26 & 10.8 \\
Total & \multicolumn{5}{c}{ Source: Fieldwork, 2019} \\
\hline \multicolumn{5}{c}{$\mathbf{1 1 6}$}
\end{tabular}

The predominance of male-headed households is in agreement with the National Population Commission (NPC) documented Household statistics of 2008, which showed that 83 per cent of households in Nigeria are headed by males while females headed only 17 per cent. However, the slight deviation from this statistics in the study area is because majority of the women bear the burden for the survival of their household unit, either as a primary bread winner due to unemployment of their husbands, who as a result had to be away, or of their unit within a polygamous homestead. Furthermore, majority of 193 respondents, representing 80.4 per cent were married. While 21 respondents or 8.8 were singles, 11 respondents (4.6\%) are divorced. Widows accounted for 15 respondents representing 6.2 per cent as depicted in Figure 2.

Occupational Dynamics: Table 2 shows the households in all identified occupations in the study area. Arable farming was the major occupation, employing 56 households in $\mathrm{A}$ as against 31 households in B.

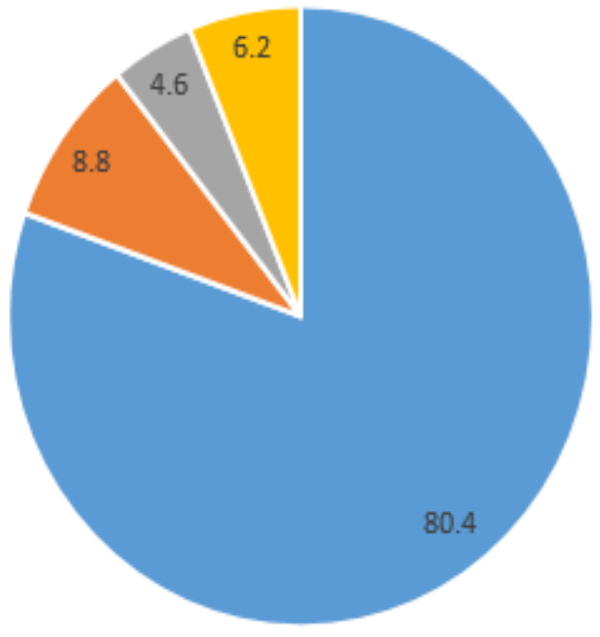

n Married - Single Divorced Widow

Fig 2: Marital Status of Household Heads (Source: Fieldwork, 2019) 
The major crops grown were cassava, sugar cane, yams, plantains, banana, maize and vegetables. Farming in the study area is not mechanized; consequently, crude implements, such as cutlasses, hoes and axes are commonly used fertility of the soil rely solely on natural processes. While 3 households were engaged in fishing in A, two households were involved in B.

Fishing is carried out in the two settlements on account of its geographical location as they are home numerous ponds and other water bodies including a creek in B.

Table 2: Occupational Characteristics of selected settlements.

\begin{tabular}{lll}
\hline Occupations & $\begin{array}{l}\text { Otor-Udu (A) } \\
\text { Frequency }\end{array}$ & $\begin{array}{l}\text { Okpare (B) } \\
\text { Frequency }\end{array}$ \\
\hline 1.Arable Farming & 56 & 31 \\
2.Animal Husbandry & 3 & 2 \\
3. Fishing & 12 & 3 \\
4. Hunting & 5 & 6 \\
5. Lumbering & 3 & 4 \\
6. Rubber Tapping & 5 & 2 \\
7. Palm nut Collection & 3 & 3 \\
8. Raffia Palm Tapping & 8 & 6 \\
9. Fuel wood Gathering & 5 & 7 \\
10. Civil Servants & 2 & 3 \\
11. Traders & 8 & 7 \\
12. Oil business & 2 & 45 \\
13. Others & 8 & 2 \\
Total & $\mathbf{1 2 0}$ & $\mathbf{1 2 0}$ \\
\hline \multicolumn{2}{c}{ Source: Fieldwork, 2019 }
\end{tabular}

60

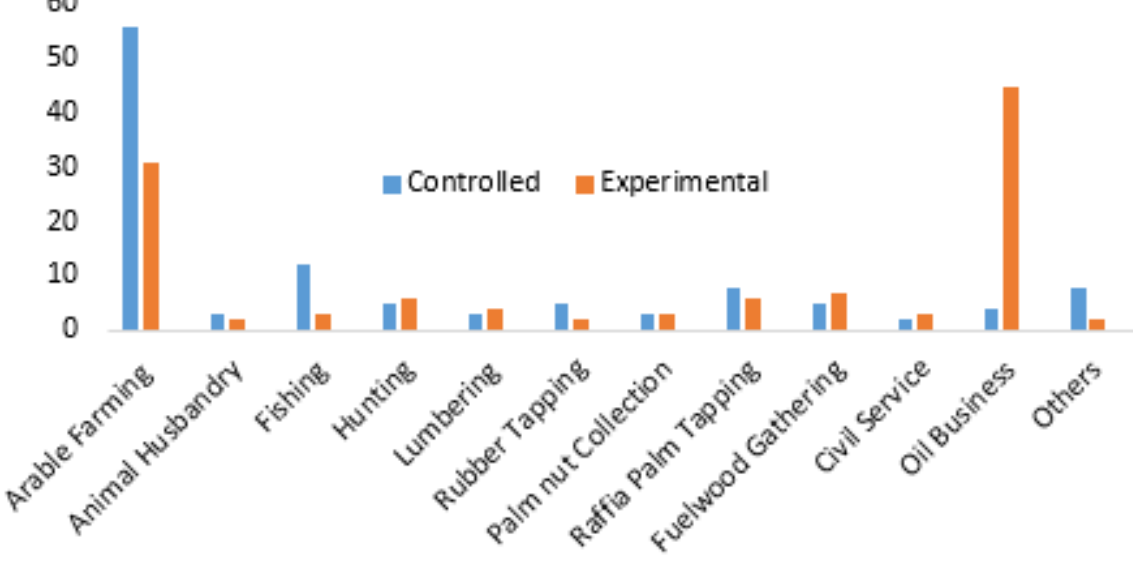

Fig 3: Occupational Distribution in Controlled and Experimental Settlements Source: Fieldwork, 2019
A total of 5 households were engaged in animal husbandry, 3 households in A and 2 households in B. Animals commonly reared are goats, sheep and pigs. Others are birds, such as fowls and ducks, and snails. While 5 households engaged in hunting in A and 6 households were engaged in B. Hunting was carried out in the fresh water swamp and the rain forest areas, using dane guns, traps, and dogs. Major games caught include antelopes, grass cutters, monkeys, porcupine and warthogs. In lumbering and rubber tapping were 4 households and 4 households, 5 households and 2 households in A and B respectively. Palm nut collection and Tapping of raffia palm (raphia hookeri) for wine and palm trees for palm nuts which is carried out exclusively by men accounted 3 households in A and 3 households in $\mathrm{B}$, and 8 households and 3 households in $\mathrm{A}$ and $\mathrm{B}$ respectively. Besides the identified primary occupations, others occupations in the study area were civil service, trading, oil business etc. Of these occupations, oil business accounted for 45 households in B and 2 households in A. While civil service accounted for 2 households and 3 households in A and B respectively, Eight (8) households and 7 households were engaged in trading in A and B respectively. Other occupations such collection of non-timber products such are thatches, screw pines for mat making, herbs for medicine, fruits and picking of snails accounted for 8 households in $\mathrm{A}$ and 2 households in B.

Table 3: Occupational Dynamics of Population

\begin{tabular}{|c|c|c|c|c|c|c|c|c|c|c|}
\hline & & \multicolumn{6}{|c|}{ Paired Differences } & \multirow{3}{*}{$\mathrm{t}$} & \multirow{3}{*}{ Df } & \multirow[b]{2}{*}{$\begin{array}{l}\text { Sig. (2- } \\
\text { tailed) }\end{array}$} \\
\hline & & & & & & $\begin{array}{r}95 \% \\
\text { Diff }\end{array}$ & $\begin{array}{l}\mathrm{L} \text { of the } \\
\text { rence }\end{array}$ & & & \\
\hline & & \multicolumn{2}{|c|}{ Mean } & Std Deviation & Std Error Mean & Lower & Upper & & & \\
\hline \multirow[t]{2}{*}{ Pair 1} & Settlement A & 9.2308 & 13 & 10.89636 & 3.98258 & & & & & \\
\hline & Settlement B & 9.3077 & 13 & 14.35940 & 3.02211 & 7.545367 & 7.39151 & .022 & 12 & .982 \\
\hline
\end{tabular}


To test the hypothesis that there is no significant difference in occupations of the population as a result of artisanal refining of crude oil, the pair-wise Student's t-test was used. The result indicated a ' $t$ ' value of 0.22 which is significant at 0.05 levels of confidence as shown in Table 3.

Conclusion: The varied occupations in the study area rely on the different components of the physical environment, which are land, water and vegetation. Therefore, any alteration in the environment as a result of artisanal refining of crude petroleum would inevitably impact on the occupational characteristics. The study revealed that there were significant dynamics in occupations as indirect impact of artisanal refining of crude oil in the study area manifested in difference in the occupations of the population in the controlled and experimental settlements.

\section{REFERENCES}

Asimiea, A; Omokhua, G. (2013). A study of environmental impact of illegal refineries on Vegetation in the Niger Delta, Nigeria. J. Agric. Soc. Res. 13 (2): 121-126.

Attah, T. (2012). Oil Theft and Artisanal (Illegal) Refining in Nigeria - Scale, Impact and the Need for a Multidimensional Responses. Proceedings of the Gulf of Guinea Security Conference, December 6, 2012. Chatham House, London

Directorate of Petroleum Resources (DPR) (2018). Illegal Artisanal Refining www.dpr.gov.ng/Illegal -artisanal Refining

Douglas, SI and Cornelius, BT (2019). Impacts of Artisanal Crude Oil Refining Activities on Soil Microorganisms. J. Adv. Bio. Biotechn. 20(3):1-9.

Igben, JL (2014). Demographic Correlates of Occupational Mobility of the Rural Population in Delta State, Nigeria. Inter. J. Res. Hum. Soc. Sci. 1(1): 18-23.
Ikporukpo, CO (1996). Federalism, political power and economic power game; conflict over access to petroleum resources in Nigeria. Environment and Planning C, Government and Policy. 14(2): 159177.

Kiikpoye, KA (2003). Human rights violation and petroleum pipeline vandalization in the Niger Delta Region. Nig. Soc. Sci. 6. (2): 17-26

National Population Commission (NPC) (2008). Nigeria demographic and health survey Calvertin, Maryland; NPC and ORC / Macro.

Niger Delta Development Commission (NDDC) (2004). Niger Delta development master plan report. September. Retrieved June 16, 2005, from http:/www.nddc.org.

Nigerian NRC (NNRC) (2014). The Environment, Social and Economic Impact of Illegal Oil Refining in the Niger Delta. Http://nigerian nrc.org/blog/anonymous/envir-soc-\&ec.impactof-illegal-oil-refining-niger-delta

Nwankwoala, HO; Harry, MT; Amangabara, GT; Warmate, T (2017). Impacts of Artisanal Refining Activities on Soli and Water Quality in parts of Okrika and Ogu-Bolo Areas of Rivers State, Nigeria. J. Environ. Anal \& Toxicol. 7(5) 503-508

Yebrade, M; Tanee, FBG (2016). Assessing the impact of Artisanal Refining on Vegetation and Soil Quality: A case study of Warri Southwest Salt Wetland of Delta State, Nigeria. Res. J. Environ. Toxic. 10(4): 205-212. 